\title{
OPINIONS OF TEACHERS ABOUT STUDENTS WITH SPECIAL EDUCATIONAL NEEDS
}

\author{
Ana-Maria SORA ${ }^{*}$, Alina-Gabriela RUSĂNESCU ${ }^{1}$ \\ ${ }^{1}$ National University of Physical Education and Sport, Faculty of Physical Education and Sport, \\ Bucharest, Romania \\ *Corresponding author: moraru.alexa.ana.maria@gmail.com
}

https://doi.org/10.35189/dpeskj.2020.59.4.9

\begin{abstract}
Inclusive education is a process aimed to respond to the diversity of children's needs by increasing their level of participation in learning and reducing their exclusion. This implies a number of substantial changes in terms of educational content, didactic and pedagogical approach, structure of the educational system and educational strategies. In order to effectively integrate students with special educational needs (SEN) in the physical education lesson, it is necessary for physical education and sports teachers to be familiar with the term "inclusive education". The aim of this research is to make a correct analysis of teachers' opinions and attitudes with regard to the integration of students with SEN in physical education lessons and to achieve a centralisation of medically exempt students in Bucharest. The research was conducted between February and June 2018 and consisted in applying a survey questionnaire among 157 physical education and sports teachers in Bucharest. The purpose was to identify their level of knowledge about inclusive physical education and to find out their opinions about the categories of students exempt from physical education classes for medical reasons and those with special educational needs in the educational establishment in which they worked. In conclusion, $98.1 \%$ of teachers have reported that they include students with SEN in physical education lessons and, due to the large number of positive responses, we can state that they are open to the new concept of inclusive education.
\end{abstract}

Keywords: inclusive physical education, special educational needs, teachers.

\section{Introduction}

Inclusive education is a process aimed to respond to the diversity of children's needs by increasing their level of participation in learning and reducing their exclusion. This implies a number of substantial changes in terms of educational content, didactic and pedagogical approach, structure of the educational system and educational strategies.

Special Educational Needs (SEN) refer to the needs of children with intellectual, sensory, psycho-motor, physiological disabilities or learning difficulties caused by psycho-emotional or socio-economic conditions that place them in a delicate situation in relation to others. These needs involve addressing the educational act from the position of a disabled student or a student with difficulties in understanding and using the learning content instead of the position of a teacher who will carry out the instructive-educational activity in the context of a homogeneous class. (Bota \& Teodorescu, 2007; Stănescu et al., 2016)

\section{Problem statement}

In recent years, specialists have shown a growing interest in identifying new methods of integrating children with special educational needs in physical education and sports classes. 
Inclusion differs from integration. The integration of children with special needs aims at including them in mainstream education and refers to the ability of a group, classroom or school to receive new members who need support for adaptation, integration and socialisation. They are usually placed in these classrooms to spend time and enjoy the necessary support. However, if this action is not accompanied by increased interaction between children with special needs and other children, it is just a step - physical integration rather than true inclusion.

Inclusion involves structural and functional changes for both parties: the one to be integrated and the one that receives/incorporates new elements. The Salamanca Declaration states that schools using inclusive orientation "are the most effective means of combating discriminatory attitudes, creating welcoming communities, building an inclusive society and providing education for all" (UNESCO, 1994, p. 9).

Inclusive education refers to overcoming all barriers to learning and ensuring the participation of all those vulnerable to exclusion and marginalisation. First of all, it is a strategic approach designed to facilitate the learning success of all children. (Merche, 2009)

"Integration" has been replaced by the term "inclusion" in the education of children with special educational needs and emphasises the restructuring of mainstream schools so that they can meet the needs of all children, regardless of ability or disability (Avramidis et al., 2000).

Physical education and sports play an important role in society and are considered a growing social phenomenon, but the current situation requires substantial improvements in the philosophy and practice of including students with SEN in physical education classes (Klavina \& Kudlacek, 2011). Unfortunately, there are no comprehensive analyses of studies focusing on the benefits of inclusive physical education (Block \& Obrusníková, 2007; O'Brien et al., 2009).

Lately, more and more answers have been sought regarding the inclusion of students with special educational needs in physical education and sports classes and the factors that influence the negative or positive attitudes of both teachers and students towards this inclusion (Tant \& Watelain, 2016; Rae et al., 2010).

At the same time, it has been established that students' attitudes towards the inclusion of children with special educational needs in physical education and sports differ depending on gender: girls have more favourable attitudes towards inclusion than boys (Hutzler, 2003; Reina et al., 2018).

One of the main factors for the successful inclusion of children with special educational needs in the class activity is the attitude of teachers (Avramidis et al., 2000; Block \& Obrusníková, 2007). Doulkeridou et al. (2011) state that it is essential for teachers to change their attitudes in order to develop more favourable behaviours towards the inclusion of students with special educational needs.

Many studies have found that teachers' attitudes vary depending on the quality of their previous contact with SEN students (Avramidis et al., 2000; Michailakis \& Reich, 2009; Bines \& Lei, 2011).

Also, many teachers report that they do not have enough experience working with SEN children to feel confident about their inclusion in the classroom (Jobling \& Moni, 2004). However, research suggests that a number of teachers working in mainstream schools feel that they have not received adequate training to meet the needs of this group of children 
(Rose, 2001). For example, physical education teachers who have not had contact with SEN students and teacher training including pedagogical practices with heterogeneous groups (e.g. adapted physical education) do not feel able to teach in inclusive environments and tend to show unfavourable attitudes towards these children (Aguiar \& Duarte, 2005; Gutierres Filho et al., 2011).

In some European countries, teachers are not allowed to decide whether or not to accept a student with special educational needs in their class but can decide to what extent they will include that student (Lienert et al., 2001).

Although there is an optimistic trend among teachers regarding the benefits of school inclusion, there are still certain factors that may hinder or make the process of school inclusion impossible. These factors are shown in Figure 1 (Mazzarino et al., 2011; Salzani Fiorini \& Manzini, 2014; Hutzler \& Barak, 2017; Hodge et al., 2018):

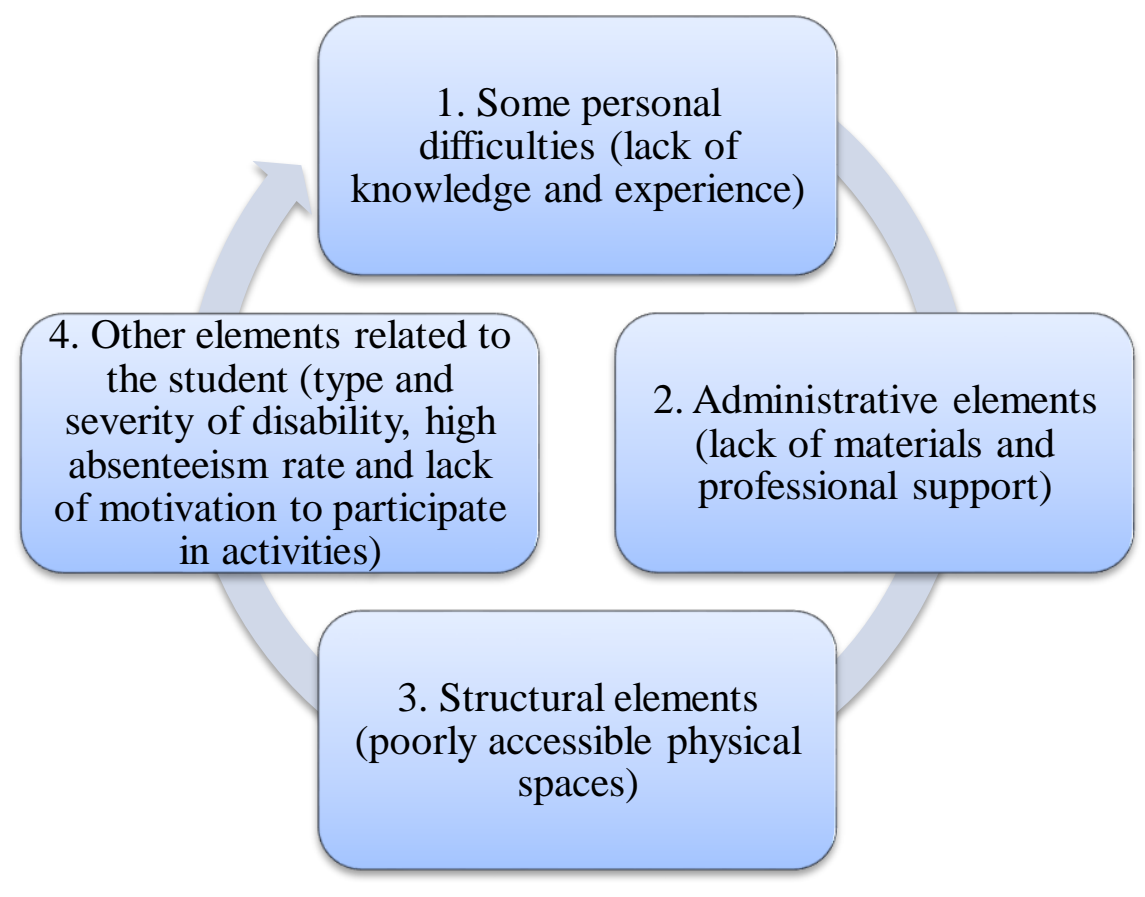

Figure 1. Factors that may hinder or make the process of school inclusion impossible

Given the research presented, it is obvious that there is sufficient information on the difficulties faced by physical education and sports teachers to include students with special educational needs. However, it is necessary to seek ways to address these difficulties, as they are still reported by teachers.

\section{Research questions}

Our research is outlined by the following research questions:

1. What is the level of teacher knowledge about inclusive education?

2. What measures and didactic strategies are used to better integrate students with SEN?

3. What are the most common categories of special educational needs? 
4. How willing are teachers to participate in continuing training on inclusive education?

Purpose of study

The purpose of this paper is to identify the opinions of teachers regarding the integration of middle-school students with special educational needs in physical education and sports classes.

\section{Methodology}

The questionnaire "Teachers' opinions on the integration of pupils with SEN in the physical education class" was applied to physical education and sports teachers in Bucharest. We mention that the research was conducted in mainstream schools.

The questionnaire is structured in two sections: the first contains identification indicators (age, gender, seniority in education and teaching degree), and the second consists of 13 items:

Q1. Do you know the meaning of "inclusive education"? Q2. In your opinion, you would define inclusive education as: Q3. Inclusive education involves working with students with special educational needs. Do you meet SEN students in your activity? Q4. If you meet SEN students in your activity, do you include them in the lesson? Q5. If so, how do you ensure their active participation? Q6. What is your attitude towards students with SEN? Q7. To what extent do you agree to include students with medical exemptions from physical education classes and those with behavioural and developmental problems in the SEN category? Q8. In the school where you work, students with medical exemptions from physical education classes suffer from: Q9. What about SEN students in your school? They suffer from: Q10. To what extent do material resources allow you to organize specific training situations for these students? Q11. According to you, which of the following factors limit the participation of SEN students in the training process? Q12. To integrate students in the lesson, you ask for help from: Q13. To what extent would you agree to participate in inclusive education training courses?

The respondents are 157 physical education and sports teachers (115 female and 42 male) in Bucharest schools (Table 1).

Table 1. Gender distribution of respondents

\begin{tabular}{lcc}
\hline & Gender & Respondents \\
\hline Female & & 115 \\
Male & & 42 \\
& Total & 157 \\
\hline
\end{tabular}

The age structure of respondents is as follows: 39 respondents are 20-30 years old, 54 are 30-40 years old, 43 are 40-50 years old, and 21 are over 50 years old (Table 2). 
Table 2. Age distribution of respondents

\begin{tabular}{rc}
\hline \multicolumn{1}{c}{ Age } & Respondents \\
\hline 20-30 years old & 39 \\
$30-40$ years old & 54 \\
40-50 years old & 43 \\
Over 50 years old & 21 \\
Total & 157 \\
\hline
\end{tabular}

According to their seniority in the field of education, 43 respondents have between 1-6 years, 26 between 6-10 years, 44 between 10-20 years, 27 between 20-30 years, and 17 have over 30 years of experience (Table 3 ).

Table 3. Distribution by seniority in the field of education

\begin{tabular}{|c|c|}
\hline Seniority in the field of education & Respondents \\
\hline $1-6$ years & 43 \\
\hline $6-10$ years & 26 \\
\hline $10-20$ years & 44 \\
\hline $20-30$ years & 27 \\
\hline Over 30 years & 17 \\
\hline Total & 157 \\
\hline
\end{tabular}

According to their teaching degree, 27 respondents have no certification degree, 43 hold a teaching certification, 27 hold a level 2 teaching certification, 58 hold a level 1 teaching certification, and 2 of them hold a $\mathrm{PhD}$ degree (Table 4).

Table 4. Distribution by teaching degree

\begin{tabular}{lc}
\hline \multicolumn{1}{c}{ Teaching degree } & Respondents \\
\hline No certification degree & 27 \\
Teaching certification & 43 \\
Level 2 teaching certification & 27 \\
Level 1 teaching certification & 58 \\
PhD $\quad$ Total & 2 \\
\multicolumn{2}{c}{$\quad 157$} \\
\hline
\end{tabular}

Distribution by sector where the school is located: 44 respondents teach in sector 1, 47 in sector 2, 19 in sector 3, 16 in sector 4, 15 in sector 5, and 17 in sector 6 (Table 5).

Table 5. Distribution by sector

\begin{tabular}{lcc}
\hline & Sector & Respondents \\
\hline Sector 1 & & 44 \\
Sector 2 & & 47 \\
Sector 3 & & 19 \\
Sector 4 & & 16 \\
Sector 5 & & 15 \\
Sector 6 & & 17 \\
& Total & 157 \\
\hline
\end{tabular}




\section{Results}

According to the responses to item 1, $49 \%$ of teachers were familiar with the term "inclusive education" to a large extent, $29.9 \%$ to a very large extent, and $12.1 \%$ said that the meaning of the term was unknown to them.

Due to the relatively new term, $8.9 \%$ of teachers gave the response "to small extent". At the same time, we noticed that those with over 30 years of seniority (14 respondents) were included in this percentage (Figure 2).

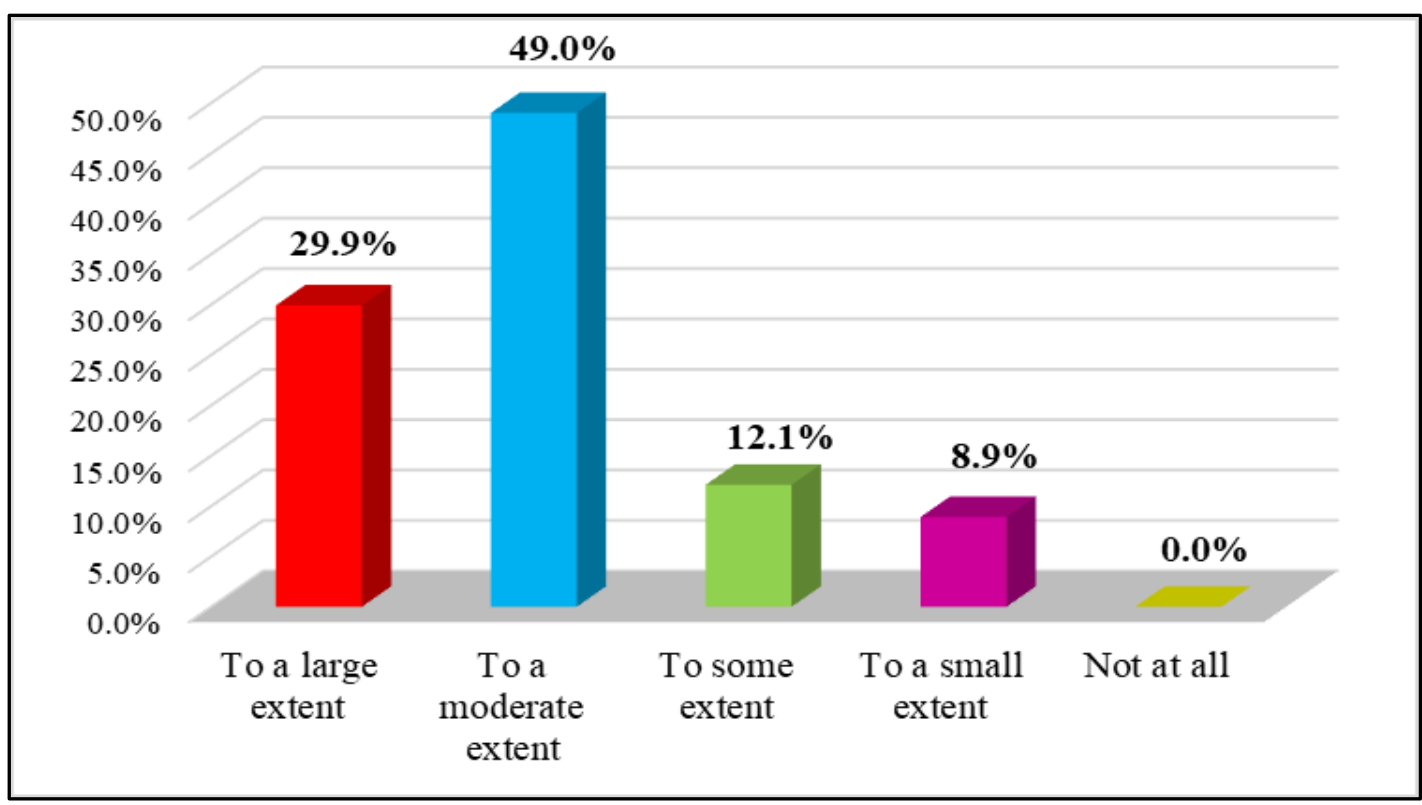

Figure 2. Q1. Do you know the meaning of "inclusive education"?

Q2. Respondents could choose from several options (Figure 3). We provided seven definitions of inclusive education, considering several points of view. The favourite response of teachers to define inclusive education was: "Content adaptation to the needs of each student" - with 64 choices (40.8\%). Another equally popular definition was: "Quality education for all children, regardless of gender, physical and intellectual characteristics or others" - with 62 choices (39.5\%). The definition "A new orientation towards the education of children with certain disabilities" collected 52 responses $(33.1 \%)$ ). "Equal opportunities for all children" gathered 50 responses (31.8\%). The definition adapted after Gherguţ (2006), "Student-focused educational activity based on their skills and needs", received 32 responses (20.4\%). The "Non-discriminatory education" option had 30 responses (19.1\%). Teachers showed that the definition "Community involvement in supporting children according to their needs" was not a very popular and common choice since the number of responses was 17 $(10.8 \%)$. 


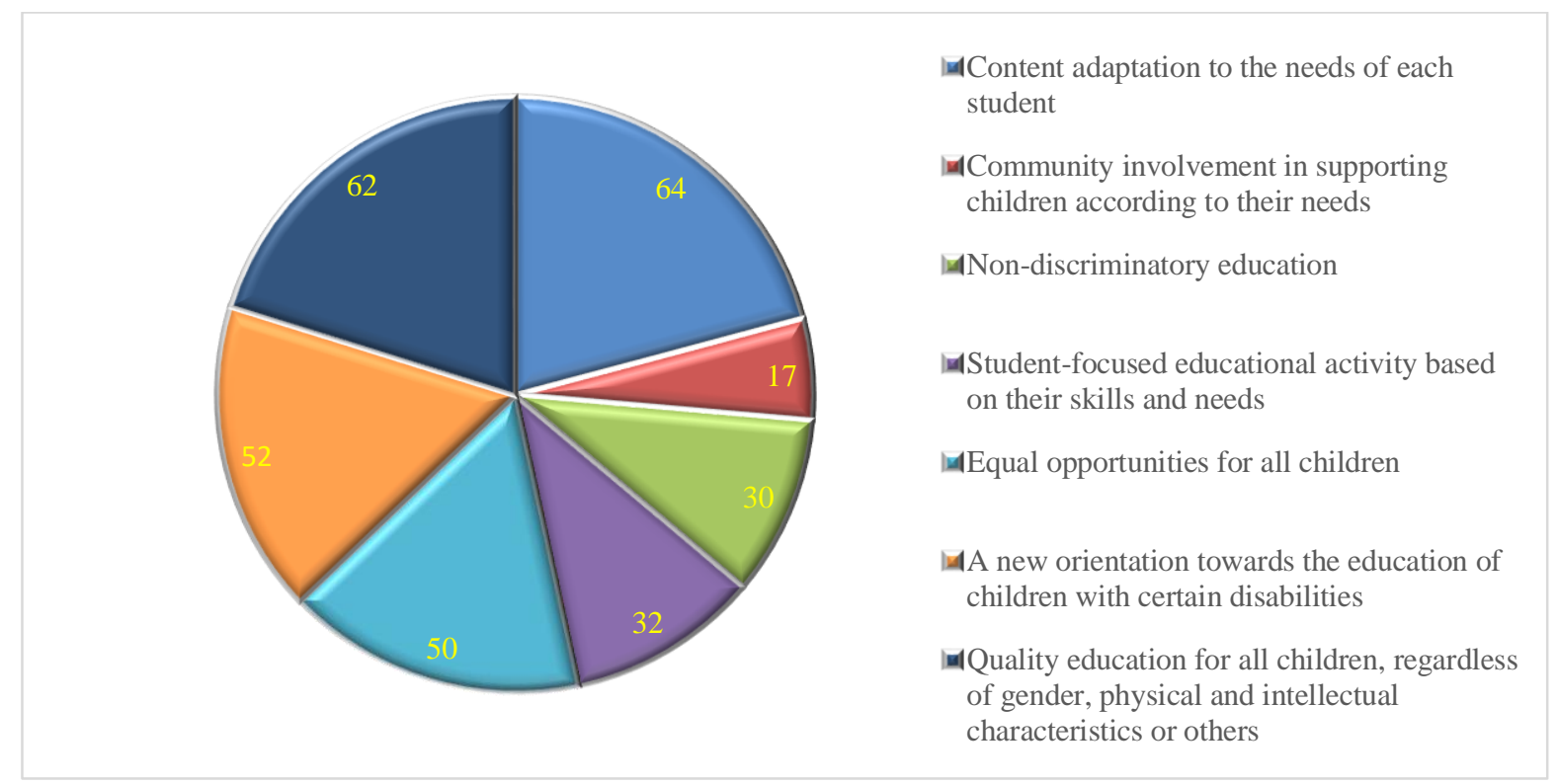

Figure 3. Q2. In your opinion, you would define inclusive education as:

At Q3, teachers were asked whether they have met students with special educational needs in their activity. 5\% (8 respondents) said "rarely" or "not at all", while the remaining 95\% said "often", sometimes even in most classrooms.

To Q4, teachers responded that they included students with special educational needs in the class activity (98.1\%, namely 154 respondents), and $1.9 \%$ (3 respondents) said that they did not include them in the class activity. Teachers' positive responses to this question highlight their openness to the new concept of inclusive education.

Q5. Responding teachers had several options, and the majority (58.5\%) believed that the active participation of students with SEN required the adaptation of the difficulty level, followed by the adaptation of training strategies (51.3\%). "Simple changes to rules and regulations" gathered a relatively small number of responses $(21.6 \%)$, and the "adjustment of materials and equipment" had $30.6 \%$ (Figure 4).

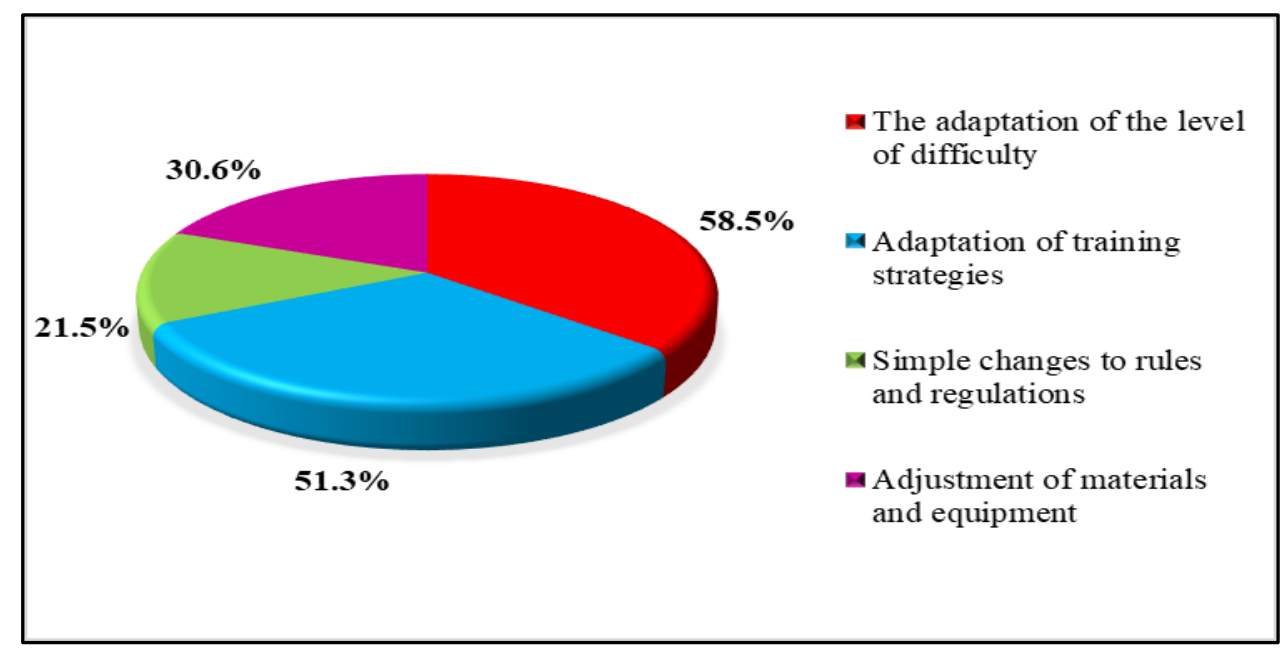

Figure 4. Q5. How do you ensure the active participation of SEN students? 
At Q6, respondents had several options for their attitude towards students with special educational needs. The majority of teachers show an attitude of acceptance - $63 \%$, understanding $-52.2 \%$, tolerance $-28.7 \%$ and avoidance $-2.5 \%$ (4 respondents).

Q7. Teachers' views on the inclusion of students with medical exemptions from physical education in the category of students with special educational needs highlight that most of them agree to this measure (28\% partial agreement, and $19.7 \%$ total agreement).

Q8. For this item, respondents had several response options. According to the graph (Figure 5), the most common is heart disease, with 86 responses, followed by respiratory diseases, with 80 responses, and orthopaedic disorders, with 56 responses. In a smaller number, behavioural disorders (31 responses), metabolic disorders (20 responses), ophthalmologic and ear-nose-throat diseases (15 responses) are reported. In the "Other" section, 1 respondent mentions Down syndrome, and 1 respondent mentions a skin disease.

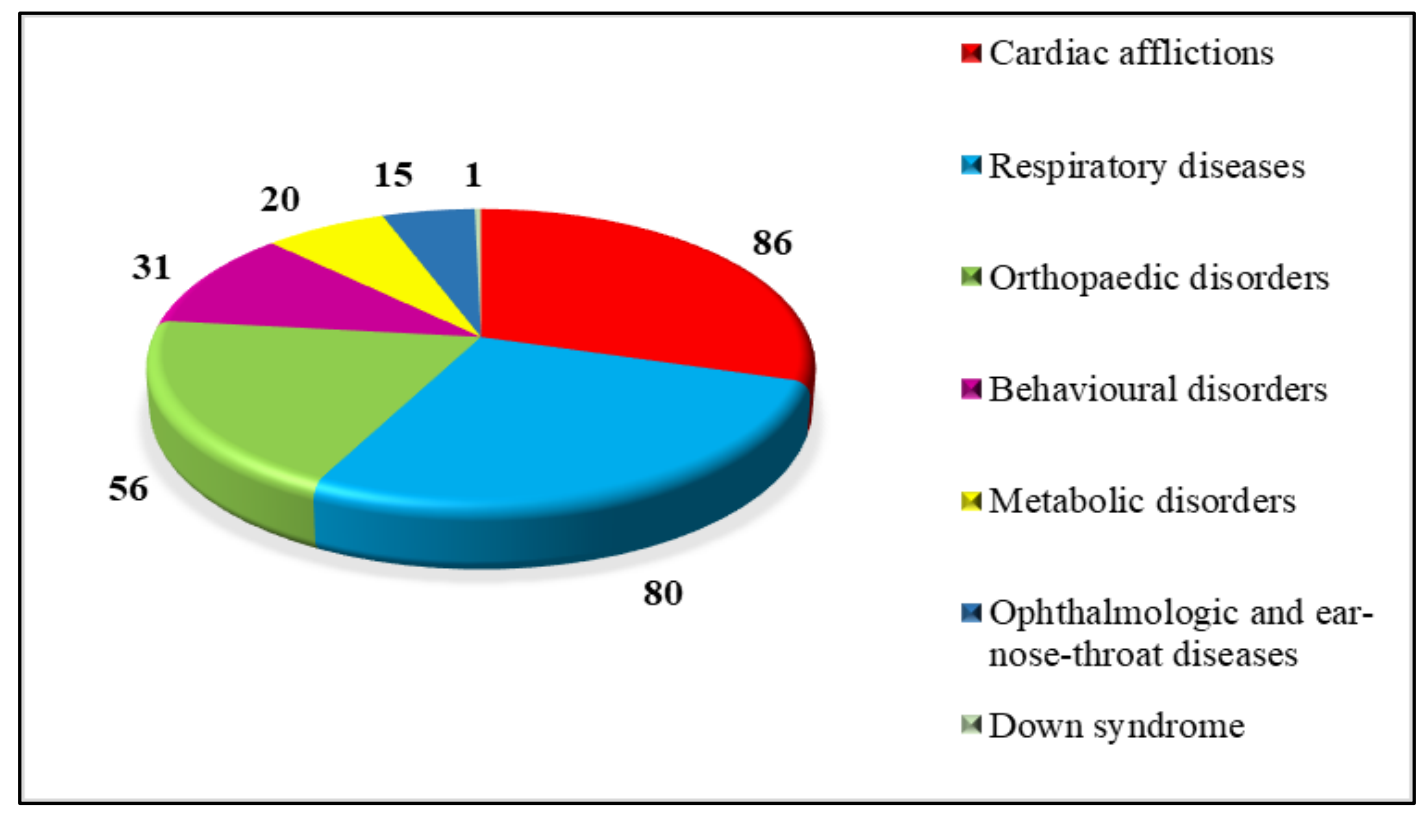

Figure 5. Q8. In the school where you work, students with medical exemptions from physical education suffer from:

Q9, about the categories of students with special educational needs in the schools where teachers worked, allowed respondents to choose from several options. According to the obtained results (Figure 6), it can be seen that the most common category is ADHD, with 95 responses, followed by the category of students with learning disabilities, with 74 responses. Autism Spectrum Disorders comes next with 64 responses. Mental challenges, language and motor disorders are also quite common choices, with 49 and 37 responses, respectively. The fewest responses refer to visual impairments (19) and hearing impairments (17). 


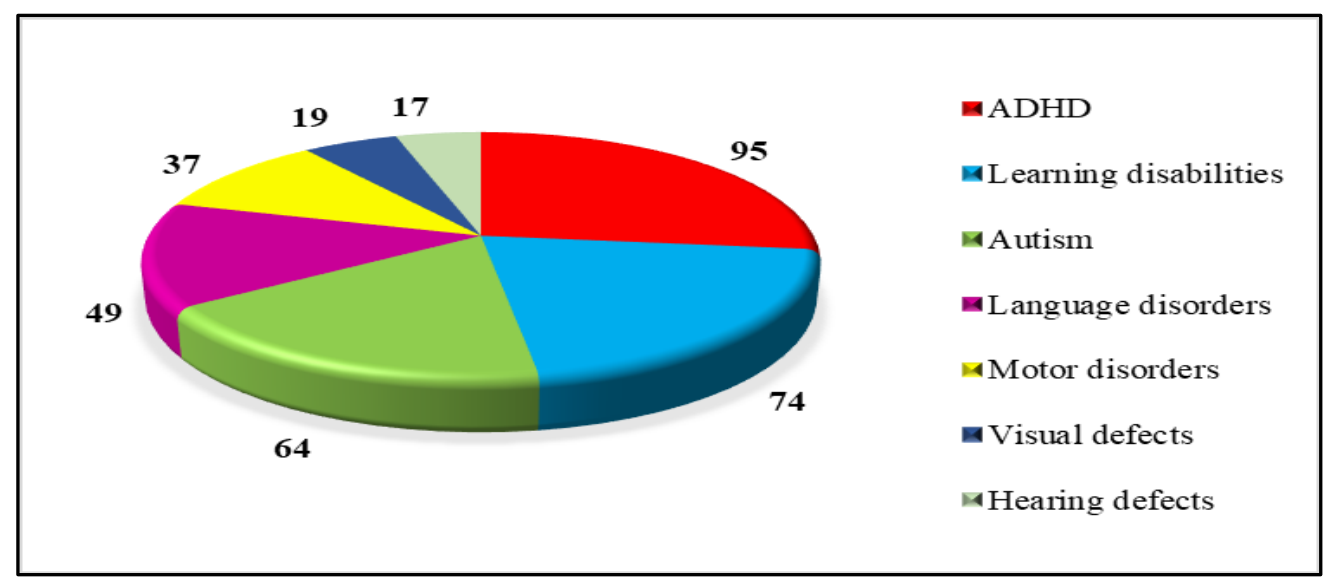

Figure 6. Q9. What about SEN students in your school? They suffer from:

Q10. According to the results, teachers do not have access to adequate equipment to organize specific training situations for these students. Thus, 34\% (53 respondents) said "to a small extent", $26.9 \%$ (42 respondents) "to a very small extent", and 23.1\% (36 respondents) "to no extent". Of those surveyed, only 4.5\% (7 respondents) said "to a large extent", meaning that the equipment allowed them to organize training situations for these students.

Q11. At the item on the factors limiting the participation of students with special educational needs in the training process, teachers could opt for several responses. They believe that the main factor limiting the participation of students with SEN in lessons is the lack of specific teacher training (104 selections). The negative attitude of the other students and their parents is equally significant. Medical problems gather a very small number of responses (14).

Q13. According to the chart, a very high percentage of teachers are interested in attending inclusive education training courses $(37.6 \%$ agree to a large extent and also $37.6 \%$ agree to a moderate extent). There are offers of continuing training in the field of inclusive education and work with SEN students, but none in the field of physical education and sports (Figure 7).

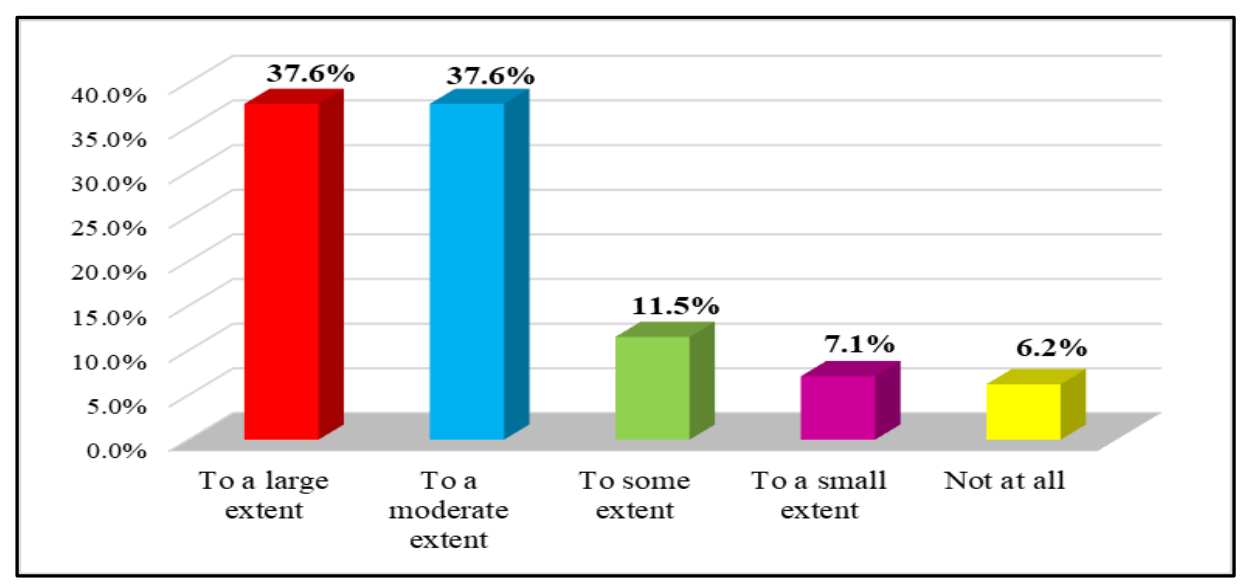

Figure 7. Q13. To what extent would you agree to participate in inclusive education training courses? 


\section{Conclusion}

The results presented in this research highlight that teachers are open to adopt the new concept of inclusive education. During classes, most teachers include students with specials educational needs in the physical education and sports lesson.

This paper has identified that more than half of the responding teachers are familiar with the term "inclusive education". Teachers' willingness to fill in their information gaps by attending training courses with topics specific to inclusive education was also noted.

In the field of physical education and in others as well, the training courses and the efforts of each teacher to stay informed about inclusive education will be decisive factors in the success of the instructive-educational approach aimed at students with special educational needs.

In physical education, an inclusive curriculum should focus on providing each student with the opportunity to experience different motor tasks, depending on the specific characteristics of each learner. Teachers believe that the active participation of students with SEN requires the adaptation of the difficulty level, followed by the adaptation of training strategies.

The paper has established a common difficulty in integrating children with special educational needs in physical education and sports classes: teachers do not have access to the material resources needed to organize specific training situations for these students, which is an important factor for integration.

For successful integration, we will have to constantly change and improve the objectives and contents of the curriculum so that it includes the diversification of educational needs that can be addressed through physical education and sports.

Most medical certificates issued to exempt students from physical education are predominantly for respiratory and cardiac diseases. Depending on the condition reported, the teacher has the role and duty to propose both students and their parents some appropriate forms of physical exercise. At the same time, teachers should be kept informed about the recommendations given by physicians with respect to the impact of these conditions in the context of exercise.

This research highlights both the opinions of teachers and possible challenges regarding the integration of students with special educational needs in the physical education class. Thus, our study is an important step towards opening new opportunities because the use of inclusive education in physical education and sports classes allows all students, regardless of disability, to develop their motor skills, improve their fitness and take care of their general health.

\section{Authors' Contributions}

Both authors have equally contributed to this study and should be considered as main authors. 


\section{Acknowledgment}

This paper is made and published under the aegis of the National University of Physical Education and Sport in Bucharest as part of the first author's doctoral studies.

\section{References}

Aguiar, J. S. de, \& Duarte, É. (2005). Educação inclusiva: Um estudo na área da educação física [Inclusive education: A study in the physical education field]. Revista Brasileira de Educação Especial, 11(2), 223-240. https://doi.org/10.1590/S1413-65382005000200005

Avramidis, E., Bayliss, B., \& Burden, R. (2000). Student teachers' attitudes towards the inclusion of children with special educational needs in the ordinary school. Teaching and Teacher Education, 16(3), 277-293. https://doi.org/10.1016/S0742-051X(99)00062-1

Bines, H., \& Lei, P. (2011). Disability and education: The longest road to inclusion. International Journal of Educational Development, 31(5), 419-424. https://doi.org/10.1016/j.ijedudev.2011.04.009

Block, M. E., \& Obrusníková, I. (2007). Inclusion in physical education: A review of the literature from 1995-2005. Adapted Physical Activity Quarterly, 24(2), 103-124. https://doi.org/10.1123/apaq.24.2.103

Bota, A., \& Teodorescu, S. (2007). Exercițiul fizic în afecțiunile cronice [Physical exercise in chronic disease]. București: Editura Didactică și Pedagogică.

Doulkeridou, A., Evaggelinou, C., Mouratidou, K., Koidou, E., Panagiotou, A., \& Kudlacek, M. (2011). Attitudes of Greek physical education teachers towards inclusion of students with disabilities in physical education classes. International Journal of Special Education, 26(1), 1-11. https://hestories.info/attitudes-of-greek-physical-education-teachers-towardsinclusi.html?page $=2$

Gherguț, A. (2006). Psihopedagogia persoanelor cu cerințe speciale. Strategii diferențiate și incluzive in educatie [Psycho-pedagogy of people with special educational needs. Differentiated and inclusive education strategies]. Iași: Polirom.

Gutierres Filho, P. J. B., Ferreira Monteiro, M. D., da Silva, R., \& Vargas, C. R. (2011). Concepções, opiniões e atitudes docentes associadas à inclusão da pessoa com deficiência na educação física: Uma revisão da produção científica brasileira [Teachers' conceptions related to inclusion of people with disabilities in physical education: A revision of the Brazilian scientific production]. Liberabit, 17(1), 19-30. http://www.scielo.org.pe/scielo.php?script=sci_arttext\&pid=S1729-48272011000100003

Hodge, S. R., Haegele, J., Gutierres Filho, P., \& Lopes, G. R. (2018). Brazilian physical education teachers' beliefs about teaching students with disabilities. International Journal of Disability, Development and Education, 65(4), 408-427. https://doi.org/10.1080/1034912X.2017.1408896

Hutzler, Y. (2003). Attitudes toward the participation of individuals with disabilities in physical activity: A review. Quest, 55(4), 347-373. https://doi.org/10.1080/00336297.2003.10491809

Hutzler, Y., \& Barak, S. (2017). Self-efficacy of physical education teachers in including students with cerebral palsy in their classes. Research in Developmental Disabilities, 68, 52-65. https://doi.org/10.1016/j.ridd.2017.07.005

Jobling, A., \& Moni, K. B. (2004). 'I never imagined I'd have to teach these children': Providing an authentic learning experience for secondary pre-service teachers in teaching students with special needs. Asia-Pacific Journal of Teacher Education, 32(1), 5-22. https://doi.org/10.1080/1359866042000206026 
Klavina, A., \& Kudlacek, M. (2011). Physical education for students with special education needs in Europe: Findings of the EUSAPA PROJECT. European Journal of Adapted Physical Activity, 4(2), 46-62. DOI: 10.5507/euj.2011.008

Lienert, C., Sherrill, C., \& Myers, B. (2001). Physical educators' concerns about integrating children with disabilities: A cross-cultural comparison. Adapted Physical Activity Quarterly, 18(1), 1-17. https://doi.org/10.1123/apaq.18.1.1

Mazzarino, J. M., Falkenbach, A., \& Rissi, S. (2011). Acessibilidade e inclusão de uma aluna com deficiência visual na escola e na educação física [Accessibility and inclusion of a pupil with visual deficiency in the school and the physical education]. Revista Brasileira de Ciências do Esporte, 33(1), 87-102. https://doi.org/10.1590/S010132892011000100006

Merche, R. H. (2009). La inclusión en el área de educación Física en España: Análisis de las barreras para la participación y aprendizaje [Inclusion in the field of physical education in Spain: Analysis of barriers to participation and learning]. Ágora para la EF y el Deporte, 9,

https://redined.mecd.gob.es/xmlui/bitstream/handle/11162/24577/00520113003054.pdf?se quence $=1 \&$ is Allowed $=\mathrm{y}$

Michailakis, D., \& Reich, W. (2009). Dilemmas of inclusive education. ALTER, European Journal of Disability Research, 3(1), 24-44. https://doi.org/10.1016/j.alter.2008.10.001

O’Brien, D., Kudláček, M., \& Howe, P. D. (2009). A contemporary review of English language literature on inclusion of students with disabilities in physical education: A European perspective. European Journal of Adapted Physical Activity, 2(1), 46-61. https://doi.org/10.5507/EUJ.2009.004

Rae, H., Murray, G., \& McKenzie, K. (2010). Teachers' attitudes to mainstream schooling. Learning Disability Practice, 13(10), 12-17. DOI: 10.7748/ldp2010.12.13.10.12.c8138

Reina, R., Hutzler, Y., Iniguez-Santiago, M. C., \& Moreno-Murcia, J. A. (2018). Student attitudes toward inclusion in physical education: The impact of ability beliefs, gender, and previous experiences. Adapted Physical Activity Quarterly, 36(1), 132-149. https://doi.org/10.1123/apaq.2017-0146

Rose, R. (2001). Primary school teacher perceptions of the conditions required to include pupils with special educational needs. Educational Review, 53(2), 147-156. https://doi.org/10.1080/00131910120055570

Salzani Fiorini, M. L., \& Manzini, E. J. (2014). Inclusão de alunos com deficiência na aula de Educação Física: Identificando dificuldades, ações e conteúdos para prover a formação do professor [Inclusion of students with disabilities in physical education classes: Identifying difficulties, actions and contents to provide training of teachers]. Revista Brasileira de Educação Especial, 20(3), 387-404. https://doi.org/10.1590/S1413-65382014000300006

Stănescu, M., Ciolcă, C., \& Stoicescu, M. (2016). Comparative analysis of the biological and motor potential of school population from Romania (urban and rural areas). In The European Proceedings of Social \& Behavioral Sciences (pp. 922-934). https://doi.org/10.15405/EPSBS.2016.09.115

Tant, M., \& Watelain, E. (2016). Forty years later, a systematic literature review on inclusion in physical education (1975-2015): A teacher perspective. Educational Research Review, 19, 1-17. https://doi.org/10.1016/j.edurev.2016.04.002

UNESCO. (1994). The Salamanca statement and framework for action on special needs education. In World Conference on Special Needs Education: Access and Quality, Salamanca, Spain, 7-10 June 1994. https://unesdoc.unesco.org/ark:/48223/pf0000098427 